\title{
ZOONOTIC CUTANEOUS LESHMAIASIS THREE YEARS FEVER HOSPITAL RECORDS: WITH GENERAL DISCUSSION
}

\author{
By \\ AMR M. EL-SAYED ABDEL-MOTAGALY ${ }^{1}$ AND TOSSON A. MORSY ${ }^{2}$ \\ Consultant of Tropical Medicine, Military Medical Academy ${ }^{1}$ and Department of \\ Parasitology, Faculty of Medicine, Ain-Shams University, Cairo $11566^{2}$, Egypt \\ Abstract
}

Leishmaniasis is widely present in more than 88 countries worldwide, resulting in up to 80,000 deaths annually. Leishmaniasis occurs as visceral, cutaneous, or mucocutaneous variants. Mucosal involvement can occur secondarily to the cutaneous or visceral varieties.

Key words: Sinai, Zoonotic cutaneous leishmaniasis, Hospitalized patients, Treatment

\section{Introduction}

Nowadays, the indigenous and exogenous cases of zoonotic cutaneous leishmaniasis (ZCL) were reported in the eastern part of the Nile Delta and Sinai Peninsula (Morsy, 1983; Abdel Wahab et al, 1986; Mansour et al, 1987; Faris et al, 1986; 1988a). This is true with the reconstruction of Sinai and the movement of temporary laborers and visitors from the neighboring endemic countries (Morsy et al, 1995). Also, a marked increased number of ZCL was reported in Suez Canal Zone (El Gibali and El Mansouri, 1979) and in South Sinai (Bassili et al, 1983). Morsy et al. (1996) reported that in the Middle East, the fat rat Psammomys obesus is the most important reservoir animal of ZCL were identified in Sinai as well as the red fox Vulpes $O$. aegyptica is a new reservoir host (Morsy et al, 2002).

This study aimed to re-evaluate ZCL situation in Sinai Peninsula as indicated by referred patients over three years

\section{Patients, Materials and Methods}

All patients were referred to Almaza Fever Hospital with cutaneous lesions suggestive of leshmaniasis during 2014-2015 were included. Patients who had skin lesions that were suspected to be cutaneous leishmaniasis. Criteria for inclusion were ages more than 18 years, presence of parasitologically confirmed leishmaniasis lesions, and nontreated previously. All were given written informed consent.

A history of liver disease, an elevated serum creatinine concentration, abnormal results on liver function tests, and allergy to fluconazole was taken. All patients with cutaneous lesions other than leishmaniasis were also excluded. All were subjected to through history and clinical medical examination basic laboratory tests: CBC, LFT, urea, creatinine, skin biopsy and Microscopic examination

- Cutaneous leishmaniasis criteria for inclusion and exclusion did not permit the enrollment of patients for whom antimony therapy was indicated according to the standard of care and if the condition progressed at any stage, the patient was switched to local treatment or antimony therapy.

All patients received a thorough history and full physical examination. Blood was obtained for liver-function tests and a renal profile. The number of Leishmania lesions was charted, along with a description of appearance, size in millimeters, location, and the presence or absence of superimposed bacterial infection. The status of each lesion was documented every two weeks for six weeks, then every month for three months. Lesions with a secondary bacterial infection were treated with topical or systemic Cephalosporin ${ }^{\circledR}$. If systemic antibiotics were required, agents with known or suspected activity against ZCL such as Rifampin ${ }^{\circledR}$ were not used.

All patients were given oral Fluconazole ${ }^{\circledR}$ 200mg daily for six weeks (Serarslan and Aksakal, 2015) with follow up for liver function tests weekly. The patients who did not respond to oral therapy were offered sodium stibogluconate (Pentostam ${ }^{\circledR}$ ) and/or cryosurgery (Morsy et al, 1989). The study end point 
was the time of lesion(s) complete healing. The need to switch to antimony compounds was excluded from the study. The study was completed at the end of the leishmanial infection season, which enrolled 209/252 subjects.

\section{Results}

A total of 126 male patients were referred to Almaza Fever Hospital during 2013-2015 with cutaneous lesions suggestive of leishmaniasis, all were immigrant workers to Sinai Peninsula, from other Egyptian Nile Valley Governorates.

The majority had multiple lesions $90 \%$, in the lower limbs (Figs. 1 \& 2), on upper limbs (Figs. $3 \& 4$ ), rare on face, mainly ear (Fig. 5). The lesions with secondary bacterial in-fections were treated by antibiotics, Fluconazole $^{\circledR} 5 \mathrm{mg} / \mathrm{kg}$ orally once daily for four weeks. A total of 126 patients with cutaneous were referred to the military fever hospital (74 in 2013; 47 in 2014 and 5 in 2015).

Some complicated lesions needed another course $(73 \%)$ and followed up to liver function tests. Complicated cases of more than 2/3 lesions with $40 \mathrm{~mm}$ diameter, cosmetic problem, LN spread. Some cases (70\%) with complex lesions after second course of Fluconazole $^{\circledR}$ were referred for cryotherapy

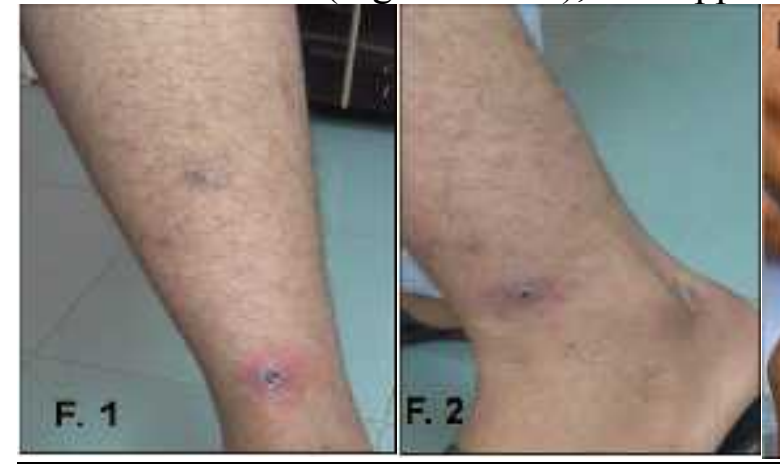

\section{Discussion}

In the present study, all patients were youth males. Lesions weather ulcerative or non-ulcerative was mainly on the upper and lower limbs, up to seven lesions were counted. Less than eleven lesions were reported in Sinai by many Egyptian authors. On the other hand, up to $75 \mathrm{ZCL}$ lesions per patient were reported in Saudi Arabia (Morsy, 1975) or even up to123/patient were reported in Iran (Nadim et al, 1968). This may indicate that the Egyptian L. major strain is not as virulent as in other Eastern Mediterranean Countries. The drop in ZCL cases from 74 in 2013 to 5 in 2015 was due to health education, using insecticides, and/or repellents, impregnated bed nets, and treated the small lesions by the local facilities.

No doubt, leishmaniasis presents a health problem worldwide (WHO, 2010). ZCL (Morsy, 1996) and IVL (Morsy, 1997) were encountered in Egypt. The cutaneous form was primarily identified in northern Sinai

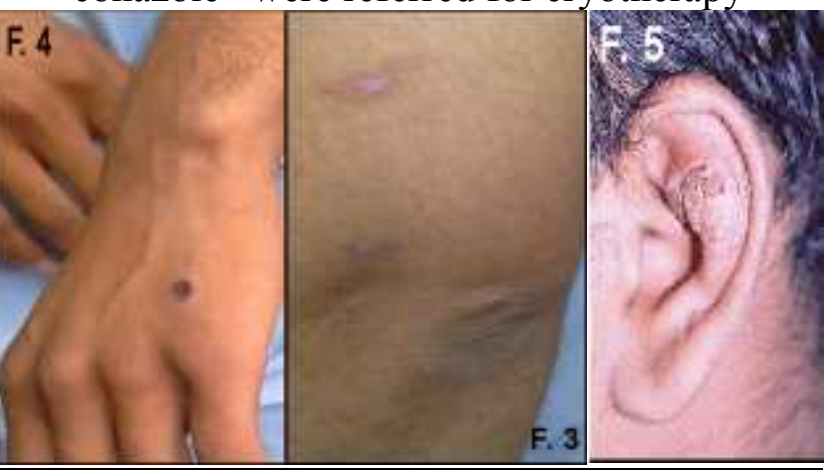

and was attributed to L. major in man and $P$. papatasii by isoenzyme typing (Wahba et al, 1990). Infantile visceral leishmaniasis was in Al-Agamy District, West of Alexandria (Faris et al, 1988a) and Dakahlia Governorate (El Mahdy et al, 1993), P. langeroni was the proven vector (Shehata et al, 1991). Faris et al. (1988b) identified two ZCL foci in North Sinai Governorate. Hanafi et al. (2001) reported $P$. sergenti, as a new vector of L. tropica (ACL), in the Nile Valley. An anthroponotic cutaneous leishmaniasis was detected in the country and transmitted by $P$. sergenti (Shehata et al, 2009) and experimental acquisition, development, and transmission of L. tropica by P. duboscqi (Hanafi et al, 2013). Unfortunately, the geographic and demographic situations in Sinai Peninsula make it a crossroads with neighboring countries where several L. major, L. tropica, $L$. donovani and the great majority of the Leishmania spp. are maintained by mammalian reservoir hosts in the natural foci of in- 
fection. Rodents, dogs, wild cats, jackals, foxes, sloths, hyraxes and other carnivores are the animal reservoirs which maintain the infection in nature. (Morsy, 1996), as well as L. ethiopica in Saudi Arabia and its animal reservoir, rock hyrax, Procavia capensis (Morsy et al, 1997a, b) and its reservoir host, parasites are endemic. Extreme weather events have occurred in recent years in Sinai, such as heavy rains and floods, leading to change in potential risks of the disease transmission by changing habitat structure for rodent reservoirs and vector populations. $P$. sergenti which was limited to the South Sinai subsequently spread to the North Sinai district as well (Fahmy et al, 2009). As a fact, the prevalence of leishmaniasis may be underestimated due to the Bedouin traditions of preventing females from visiting clinics and their dependence on routine heat therapy for the treatment, besides it is not a $\mathrm{MOH}$ reportable disease In Sinai Peninsula, different habitats are present in which human populations are either scattered across the desert or live in villages where people from different parts of Egypt work or live. These human activities along with potential changes in climate may create new risk factors for CL distribution in Egypt

El Bahnasawy et al. (2013) reported $P$. langeroni in the Egyptian Northern Coastal Zone, but not in Alexandria. Urbanization of the north coastal zone of Egypt dramatically changed the ecology of $P$. langeroni. The fig trees, which offer sugar meal source for sand flies are no longer there at least in Al-Agmy district and modern buildings are now made from concrete while Bedouins' houses used to be made from local limestone that served as suitable niches for sand fly resting. Furthermore stray dogs that act as animal reservoir were eliminated (Kassem et al, 2012). $P$. langeroni that was no longer present in El-Agamy was again detected in cities more to the west of Alexandria. This can give a possibility of re-appearance of infantile VL in these areas with the return of the Egyptian employees and their families from Libya
(El-Bahnasawy et al, 2013). Animal reservoir hosts, domestic dogs in Al-Agamy, Alexandria Governorate were found naturally infected with L. major (Morsy et al, 1987), L. major in Meriones sacramenti in Nakhl, North Sinai Governorate (Morsy et al, 1993a), two stray dogs and two Gerbillus pyramidum in Dakahlia Governorate (Morsy et al, 1994) and stray dogs with visceralized Leishmania species (Rosypal et al, 2012).

Morsy et al. (1993b) studied seasonal abundance, nocturnal activity, breeding sites and other relevant behavior P. papatasi, the proven vector of the ZCL. They showed that a- the seasonal activity started in April and ended in November or beginning of December, $b$ - female outnumbered male indoors (7.4:1) and vise-versa was outdoors (0.14:1), c- blood fed females were $97.7 \%$ indoors and $29.4 \%$ outdoors, d- nocturnal activity between 6 p.m. to 6 a.m. indoors and 8 p.m. to 6 a.m. outdoors and e- sand-fly immature stages were recovered from the rodent burrows and poultry sheds. Saleh et al. (2015) stated the prevalent of ZCL in Sinai Peninsula with at least three identified foci.

On the other hand, Morsy et al. (1997c) reported L. major in an Egyptian patient manifested as diffuse cutaneous leishmaniasis (DCL). Ara et al. (1998) in Spain reported visceral leishmaniasis infection with cutaneous lesions in a patient infected with human immunodeficiency virus. Colebunders et al. (1999) in Belgium reported cutaneous leishmaniasis lesions in two patients with visceral leishmaniasis and HIV infection. Catorze et al. (2006) in Portugal reported L. infant$u m / \mathrm{HIV}$ co-infection with cutaneous lesions following visceral leishmaniasis treatment. Karamian et al. (2007) in Iran detected $L$. major infection in a patient with visceral leishmaniasis. Gonzalez-Beato et al. (2010) in Spain reported Kaposi's sarcoma-like lesions and other nodules as cutaneous involvement in AIDS-related visceral leishmaniasis. Alborzi et al. (2013) in Iran reported a case of mucocutaneous leishmanias. Babiker et al. (2016) in Sudan detected concomitant infec- 
tion with $L$. donovani and L. major in single ulcers of cutaneous leishmaniasis patients. Moreno Martínez et al. (2016) in Spain stated CL as an opportunistic infection.

Apart from Egypt, zoonotic or anthroponotic cutaneous and/or visceral leishmaniasis were reported in all Eastern Mediterranean Countries as in Iraq (Jarallah, 2014), Jordan (Mukbel et al, 2016), Kuwait (Alsaleh et al, 1995), Libya (Samy et al, 2016), Lebanon (Alawieh et al, 2014), Palestine (Al-Jawabreh et al, 2016), Saudi Arabia (Zhang et al, 2016), Sudan (Karimkhani et al, 2016), Syria (Mondragon-Shem and Acosta-Serrano, 2016), Tunisia (Attia et al, 2016), Yemen (Mogalli et al, 2016), and other countries (Morsy, 2013). Many Egyptian temporary workers, employees as well as visitors from all these regional countries travel here and there to these countries and others.

\section{Conclusion}

Leishmaniasis either cutaneous and/or visceral is encountered worldwide particularly in the Eastern Mediterranean Countries. Controlling of rodents and sand-fly is a must especially in the inhabited areas. No doubt, the endemic ZCL foci in Sinai and the presence of many animal reservoir hosts and abundance of the insect-vector; $P$. papatasi are well documented.

On the other hand, the presence of $P$. sergenti the known vector of anthroponotic cutaneous leishmaniasis in North Sinai and endemic foci of man to man transmitted leishmaniasis in at least three neighboring countries must be taken into consideration by the Egyptian Public Health Authorities.

\section{References}

Abdel Wahab, RM, Morsy, TA, EI Garem, A A, Bahgat, A, Essa, MH, 1986: Introduced cases of cutaneous leishmaniasis in Egypt. J. Egypt. Soc. Parasitol. 16, 1:9-16.

Alawieh, A, Musharrafieh, U, Jaber, A, Berry, A, Ghosn, N, et al, 2014: Revisiting leishmaniasis in the time of war: the Syrian conflict and the Lebanese outbreak. Int. J. Infect. Dis. 29:115-9.

Alborzi, A, Pouladfar, GR, Ghadimi Moghadam, A, Attar, A, Drakhshan, N, et al, 2013: Fi- rst molecular-based detection of mucocutaneous leishmaniasis caused by Leishmania major in Iran. J. Infect. Dev. Ctries 7, 5:413-6.

Al-Jawabreh, A, Dumaidi, K, Ereqat, S, AlJawabreh, H, Nasereddin, A, et al, 2016: Molecular epidemiology of human cutaneous leishmaniasis in Jericho and its vicinity in Palestine from 1994 to 2015. Infect. Genet. Evol. 2016 Jun 5. pii: S1567-1348(16)30231-3.

Alsaleh, QA, Dvorak, R, Nanda, A, 1995: Ketoconazole in the treatment of cutaneous leishmaniasis in Kuwait. Int. J. Dermatol. 34, 7:495-7.

Ara, M, Maillo, C, Peon, G, Clavel, A, Cuesta, J, et al, 1998: Visceral leishmaniasis with cutaneous lesions in a patient infected with human immunodeficiency virus. Br. J. Dermatol. 139, 1:114-7.

Attia, H, Sghaier, RM, Gelanew, T, Bali, A, Schweynoch, C, et al, 2016: Genetic micro-heterogeneity of Leishmania major in emerging foci of zoonotic cutaneous leishmaniasis in Tunisia. Infect. Genet. Evol. 43:179-85.

Babiker, AM, Ravagnan, S, Fusaro, A, Hassan, MM, Bakheit, SM, et al, 2014: Concomitant infection with Leishmania donovani \& L. major in single ulcers of cutaneous leishmaniasis patients from Sudan. J. Trop. Med.:170859. doi: 10.1155/2014/170859. Epub 2014 Mar 12.

Bassili, WR, Morsy, TA, Michael, SA, 1983: Specific and sensitivity of indirect haemagglutination tests in patients with cutaneous leishmaniasis. J. Egypt. Soc. Parasitol. 13:291-5.

Beier, JC, El Sawaf, BM, Merdan, AI, EI Said, S, Doha, S, 1986: Sand flies (Diptera: Psychodidae) associated with visceral leishmaniasis in El Agamy, Alexandria Governorate, Egypt. J. Med. Entomol. 23, 6:600-8.

Catorze, G, Alberto, J, Afonso, A, Vieira, R, Cortes, S, et al, 2006: Leishmania infantum/ HIV co-infection: Cutaneous lesions following treatment of visceral leishmaniasis. Ann. Dermatol. Venereol. 133, 1:39-42.

Colebunders, R, Depraetere, K, Verstraeten, T, Lambert, J, Hauben, E, et al, 1999: Unusual cutaneous lesions in two patients with visceral leishmaniasis and HIV infection. J Am Acad Dermatol. 41, 5; Pt2:847-50.

El-Bahnasawy, MM, Ahmed, GM Gaber, W A, Morsy, TA, 2013: The infantile visceral leishmaniasis: Could it attack Egyptian north coastal region again? J. Egypt. Soc. Parasitol. 43: 601-8.

El Gibali, MR, El Mansouri, H, 1979: Pyrime- 
thamine in prophylaxis and treatment of cutaneous leishmaniasis. Armed Forces Med. J. 11: 109-13.

El Mahdy, A, Morsy, TA, Youssef, MS, el Shazly, AM, Hammoda, NE, 1993: Visceral leishmaniasis among hypersplenic patients in Dakahlia Governorate, Egypt. J. Egypt. Soc. Parasitol. 23, 2:563-77.

Fahmy, AR, Samy, AM, Doha, SA, Shehata, MG, 2009: Preliminary field investigations on phlebotomine sandflies (Diptera: Psychodidae) from a recent cutaneous leishmaniasis focus in Northern-Sinai, Egypt. Egypt. Acad. J. Biol. Sci. 2: 9-15

Faris, R, Feinsod, FM, Morsy, TA, EIMissiry, AG, Gabal, MS, et al, 1988a: Human cutaneous leishmaniasis in two communities in Eastern Sinai, Egypt. Eur. J. Epidemiol. 4, 1:45-8.

Faris, R, Massoud, A, el Said, S, Gadallah, M A, Feinsod, FM, et al, 1988b: The epidemiology of human visceral leishmaniasis in El Agamy (Alexandria Governorate), Egypt: Serosurvey and case/control study. Ann. Trop. Med. Parasitol. 82, 5:445-52.

Faris, R, Morsy, TA, Feinsod, FM, Gabal, S, EIMissiry, AG, et al, 1986: Population based studies of cutaneous leishmaniasis in North Sinai. Ann. Meet. Am. Soc. Trop. Med. Hyg. Denver, Co., USA.

Hamadto, HA, EI Fakahany, AF, Morsy, TA, Farrag, A, Abdel Maksoud, KhM, 2003: Reevaluation of zoonotic cutaneous leishmaniasis status in North Sinai Governorate, Egypt. J. Egypt. Soc. Parasitol. 33, 3:687-94.

Hanafi, HA, Beavers, GM, Dykstra, EA, 2001: New record of Phlebotomus sergenti, the vector of Leishmania tropica, in the southern Nile valley of Egypt. J. Am. Mosq. Control Assoc. 17, 4:272-4.

Hanafi, HA, El-Din el-SM, El-Hossary, SS, Kaldas, RM, Villinski, JT, et al, 2013: Experimental acquisition, development, and transmission of Leishmania tropica by Phlebotomus duboscqi. Acta Trop. 125, 1:37-42.

Gonzalez-Beato, MJ, Moyano, B, Sanchez, C, Gonzalez-Beato, MT, Perez-Molina, JA, et al, 2000: Kaposi's sarcoma-like lesions and other nodules as cutaneous involvement in AIDS-related visceral leishmaniasis. Br. J. Dermatol. 143, 6:1316-8

Jarallah, HM, 2014: Cutaneous leishmaniasis in Basrah Villages, South Iraq. J. Egypt. Soc. Parasitol. 44, 3:597-603.
Karamian, M, Motazedian, MH, Mehrabani, D, Gholami, K, 2007: Leishmania major infection in a patient with visceral leishmaniasis: Treatment with Amphotericin B. Parasitol. Res. 101, 5:1431-4.

Kassem, HA, EL Nogoumy, NN, EL Sawaf, B M, 2012: Impact of urbanization on the sand fly Phlebotomus langeroni Nitzulescu in an old focus of visceral leishmaniasis in Egypt. J. Egypt. Soc. Parasitol. 42, 2:619-24

Mansour, NS, Youssef, FG, Mohareb, EW, Dees, WH, Karuru, ER, 1987: Cutaneous leishmaniasis in north Sinai. Trans. R. Soc. Trop. Med. Hyg. 81, 5:747.

Mogalli, NM, El Hossary, SS, Khatri, ML, Mukred, AM, Kassem, HA, et al, 2016: Clinicoepidemiologic pattern of cutaneous leishmaniasis and molecular characterization of its causative agent in Hajjah governorate, northwest of Yemen. Acta Trop. 163:130-4.

Mondragon-Shem, K, Acosta-Serrano, A, 2016: Cutaneous Leishmaniasis: Truth about the 'Flesh-eating disease' in Syria. Trends Parasitol. $32,6: 432-5$.

Moreno Martínez, MJ, Moreno Ramos, MJ, Sánchez Pedreño, P, 2016: Cutaneous leishmaniasis: An opportunistic infection. Reumatol. Clin. Sep 15. pii: S1699-258X(16)30065-1.

Morsy, TA, 1975: Oriental sore in Riyadh, Saudi Arabia. Castellania: Tropenmed. Dermatol. 3, 8:155-7, Acron, Verlag, Berlin.

Morsy, TA, 1983: Cutaneous leishmaniasis in Egypt. J. Egypt. Soc. Parasitol. 13, 2:597-611.

Morsy, TA, 1996: Cutaneous leishmaniasis in Egypt: Review and comment. J. Egypt. Soc. Parasitol. 26, 1:105-30.

Morsy, TA, 1997: Visceral leishmaniasis with special reference to Egypt (Review and comment). J. Egypt. Soc. Parasitol. 27, 2:373-96.

Morsy, TA, 2013: Cutaneous leishmaniasis predisposing to human skin cancer: Forty years local and regional studies. J. Egypt. Soc. Parasitol. 43, 3:629-48.

Morsy, TA, Abouel-Seoud, SM, 1994: Natural infection in two pet cats in a house of a zoonotic cutaneous leishmaniasis patient in Imbaba area, Giza Governorate, Egypt. J. Egypt. Soc. Parasitol. 24, 1:199-204

Morsy, TA, Schnur, LF, Feinsod, FM, Salem, AM, Wahba, MM, et al, 1987: Natural infections of Leishmania major in domestic dogs from Alexandria, Egypt. Am. J. Trop. Med. Hyg. 37, 1:49-52. 
Morsy, TA, Abdel Rahman, EG, Ahmed, M M, 1989: Treatment of cutaneous leishmaniasis with Pentostam or cryosurgery. J. Egypt. Soc. Parasitol.19, 2:533-43.

Morsy, TA, Kenawi, MZ, Abdalla, KF, Saleh, MH, Rezalla, S, 1991: Two indigenous cases of cutaneous leishmaniasis in Qualyobia G. Egypt. J. Egypt. Soc. Parasitol. 21, 3:779-83.

Morsy, TA, EI Kady, GA, Salama, MMI, Habib, KMS, Ghareb, MA, 1993a: Leishmania ma-jor in Meriones sacramenti Thomas 1992 in Nakhl, North Sinai, Egypt. J. Egypt. Soc. Parasitol. 23, 2:371-9.

Morsy, TA, Aboul Ela, RG, Sarwat, MA, Arfa, MA, el Gozamy, BM, 1993b: Some aspects of Ph. papatasi (Scopoli) in greater Cairo, Egypt. J. Egypt. Soc. Parasitol. 23, 2:399-416

Morsy, TA, el Shazly, AM, el Kady, GA, Sabry, AH, Handousa, AA, et al, 1994: Natural Leishmania infections in two stray dogs and two Gerbillus pyramidum in Dakahlia Governorate, Egypt. J. Egypt. Soc. Parasitol. 24, 2: 383-94

Morsy, TA, Naser, AM, El Gibali, MR, Anwar, AM, El Said, AM, 1995: Studies on zoonotic cutaneous leishmaniasis among a group of temporary workers in North Sinai Governorate, Egypt. J. Egypt. Soc. Parasitol. 25, 1:99-106.

Morsy, TA, Sabry, AA, Rifaat, MMA, Wahba, MM, 1996: Psammomys obesus Cretzchmar, 1828 and zoonotic cutaneous leishmaniasis in Sinai Peninsula, Egypt. J. Egypt. Soc. Parasitol. 26, 2:375-81.

Morsy, TA, Al Dakhil, MA, El Bahrawy, AF, 1997a: Natural Leishmania infection in rock hyrax, Procavia capensis (Pallas, 1766) order: Hyracoidea, trapped in Najran, Saudi Arabia. J. Egypt. Soc. Parasitol. 27, 1:75-81.

Morsy, TA, Al Dakhil, MA, El Bahrawy, AF, 1997b: Characterization of Leishmania aethiopica from rock hyrax, Procavia capensis trapped in Najran, Saudi Arabia. J. Egypt. Soc. Parasitol. 27, 2:349-53.

Morsy, TA, Ibrahim, BB, Lashin, AH, 1997c: Leishmania major in an Egyptian patient manifested as diffuse cutaneous leishmaniasis. J. Egypt. Soc. Parasitol. 27, 1:205-10.

Morsy, TA, Saleh, WA, Ismail, MAM, 2002: The red fox Vulpes O. aegyptica, a new host of Leishmania major in Sinai Peninsula. J. Egypt. Soc. Parasitol. 32, 3:737-43.

Mukbel, RM, Khasharmeh, RH, Hijjawi, NS, Khalifeh, MS, Hatmal, MM, et al, 2016: Hu- man immune response to salivary proteins of wild-caught Phlebotomus papatasi. Parasitol. Res. 115, 9:3345-55.

Nadim, A, Mesghali, A, Amini, H, 1968: Epidemiology of cutaneous leishmaniasis in the Isfahan province of Iran. Trans. R. Soc. Trop. Med. Hyg. 62, 4:543-9.

Karimkhani, C, Wanga, V, Coffeng, LE, Naghavi, P, Dellavalle, RP, et al, 2016: Global burden of cutaneous leishmaniasis: A cross-sectional analysis from the global burden of disease study 2013. Lancet Infect. Dis. 16, 5:584-91.

Rosypal, AC, Bowman, SS, Epps, SA, EI Behairy, AM, Hilali, M, et al, 2013: Serological survey of dogs from Egypt for antibodies to Leishmania species. J. Parasitol. 99:170-1

Saleh, AM, Labib, A, Abdel-Fattah, MS, AlAttar, MB, Morsy, TA, 2015: Sand-fly Phlebotomus papatasi (Phlebotominae): A general review with special reference to zoonotic cutaneous leishmaniasis in Egypt. J. Egypt. Soc. Parasitol. 45, 3:525-44.

Samy, AM, Annajar, BB, Dokhan, MR, Boussaa, S, Peterson, AT, 2016: Coarse-resolution ecology of etiological agent, vector, and reservoirs of zoonotic cutaneous leishmaniasis in Libya. PLoS. Negl. Trop. Dis. 2016 Feb 10; 10 (2): e0004381.

Serarslan, G, Aksakal, M, 2015: Cutaneous leishmaniasis mimicking granulomatous cheilitis and treated successfully with oral fluconazole in a boy. Ann. Parasitol. 61, 3:197-9.

Shehata, M, El Sattar, S, Morsy, TA, El Sawaf, BM, 1991: Experimental dual infections in Phlebotomus langeroni Nitzulescu (Diptera: Psychodidae). Trans. Roy. Soc. Trop. Med. Hyg. 85, 6:739-40.

Shehata, MG, Samy, AM, Doha, SA, Fahmy, AR, Kaldas, RM, et al, 2009: First report of Leishmania tropica from a classical focus of L. major in North-Sinai, Egypt. Am. J. Trop. Med. Hyg, 81:213-8

Wahab, MM, Schnur, LE, Morsy, TA, Merdan, A, 1990: The characterization of Leishmania major from Phlebotomus papatasi. J. Trop. Med. Hyg. 84:758-9.

WHO, 2010: Control of the leishmaniases. Technical report series xii-xiii, 1-186, back cover.

Zhang, M, Liu, F, Liu, H, Hu, W, Sang, H, 2016: Imported cutaneous leishmaniasis caused by L. major in a Chinese laborer who worked in Saudi Arabia. Ann. Bras. Dermatol. 91, 3:365-7 